\title{
La responsabilidad social empresarial y el modelo de excelencia EFQM como marco de integración de los sistemas de gestión en las organizaciones
}

\section{Corporate social responsibility and the EFQM excellence model as a frame work for integration of management systems in organizations}

\author{
Martha L. Quintero-Garzón*§, Andrés Carrión-García**, Ma. Aurora Jordá- \\ Rodríguez***, Ma. del Pilar Rodríguez-Córdoba**** \\ *Escuela de Ingeniería Industrial. Universidad del Valle. Cali, Colombia. \\ ** Departamento de Estadística e Investigación Operativas Aplicadas y Calidad. \\ Universidad Politécnica de Valencia. Valencia, España. \\ ***Departamento de Organización de Empresas. Universidad Politécnica de Valencia. Valencia, España. \\ ****Facultad de Ingeniería. Universidad Nacional de Colombia. Manizales, Colombia. \\ smartha.quintero@correounivalle.edu.co,acario@eio.upv.es,ajorda@omp.upv.es,mdrodriguezco@unal.edu.co.
}

(Recibido: septiembre 20 de 2013 - Aceptado: marzo 18 de 2015 )

\begin{abstract}
Resumen
La Responsabilidad Social Empresarial (RSE) es hoy un tema obligado en las organizaciones. Se empieza a reconocer que las empresas, además de producir bienes y servicios, son también responsables de los riesgos que generan, no sólo para sus trabajadores, sino por la contaminación al medio ambiente. Ésta investigación se desarrolló con el propósito de definir un marco de integración para los sistemas de gestión en calidad, ambiental y salud ocupacional, tomando la RSE y el modelo de excelencia EFQM como base. Entre los resultados se tiene la generación de un modelo bajo los principios de la RSE y de indicadores con los cuales la gerencia pueda medir la madurez de su RSE. Con ello se propone que muestren su RSE, mediante las buenas acciones que una organización demuestre desde el punto de vista empresarial: no contaminación, respeto y preocupación por sus trabajadores, clientes y Stakeholders. Se proporciona, por tanto, a las organizaciones una justificación válida para incursionar en acciones de RSE, de tal manera que integrando este concepto en su estrategia básica y en su sistema de gestión global, serán más productivas y podrán convertirse en empresas competitivas y socialmente responsables con criterios de excelencia.
\end{abstract}

Palabras clave: Gestión sostenible integral, modelo de excelencia EFQM, responsabilidad social empresarial, sistemas de gestión.

\begin{abstract}
Corporate Social Responsibility (CSR) is an important topic for modern organizations. Companies around the world recognize that their purpose is not only manufacturing products or services; they are also responsible for the risks that can affect not only their workers but the environment as well.This research was conducted with the main objective of defining an integration framework for quality, environmental, and occupational health management systems based on CSR and the EFQM excellence model. This research project tends to be explanatory and oriented to theoretical structures, and because of its methodological approach and foundations we used qualitative and quantitative tools. After this, we used quantified information through case studies.As a result, we generated a model under the CSR guiding principles and indicators that can help measure the maturity of a company's CSR.A valid justification is given for organizations to start taking CSR actions, in such a way that they can integrate CSR in their base strategy and in their global management system. The benefits of doing this are improvements in productivity and that organizations can become competitive and socially responsible with excellence criteria.
\end{abstract}

Keywords: Comprehensive sustainable management, corporate social responsibility, management systems. 


\section{Introduction}

Corporate Social Responsibility, from now on CSR, was seen a few years ago as the "economic contribution" that an organization gave to stakeholders, as retribution for any damage caused to the environment or to be seen as a generous organization that shares benefits with others.

Some organizations, on the other hand, saw it as an obligation beyond the economic factor, so they were afraid to commit to any initiative, because it did not belong to the core purpose of their organizations (the distribution of earnings among the shareholders or the owners of the company), so the was no interest in participating in any CSR initiative.

As time passed by, companies started to notice that CSR did show gains to those that started to involve it as part of their day to day operations. Processes and their execution began to be revised, not only for their generation of financial gains but also for their impact on the well being of employees, society at large and their impact on the environment (Cortina, 2005; García-Marza, 2006).

With this research we want to show companies not only the importance of the concept of CSR, but how such a concept can be tied with the excellence models and the integration that can be done with the quality, environmental, and occupational health and safety management systems. Also, to provide them with continuous improvement tools that will help them to increase their productivity, integrating CSR to the basic strategy and in the global management system. Approaching CSR as a differential competitive advantage, can contribute to a real Comprehensive Sustainable Management.

This CSR concept is not new, the innovation was how it was used in this research; that is, presenting the relationship it poses with the comprehensive management system, that encompasses the quality, environmental, security and occupational health systems in the organization. In this way, the intention is to generate a change of attitudes in the organization and in the community, related to the concept of CSR and the impact its involvement on the global management of companies has on society.
To justify this proposal, the methods employed, and the results obtained will be presented, as well as some of the key concepts included in this subject.

\section{Methodology}

To generate the methodological model of the Comprehensive Sustainable Management, we analyzed the integration between management systems, the EFQM model and the principles of CSR.

This analysis started with the study of the individual relationship between the principles of each management system and the foundations of the EFQM excellence model. Next, we established the relationship between the individual criteria of each management norm and the EFQM model criteria. (See example for EMS in Table 1, Table 2 and Table 3). Finally, we showed the relationship between the Integrated Management System (IMS) and the principles of Corporate Responsibility consigned in the ISO 26000:2010 and the GTC 180 in RS (GTC 180, 2008). These relationships constitute the foundation for the generation of the COMPREHENSIVE SUSTAINABLE MANAGEMENT SYSTEM (Quintero, 2012).

We demonstrated that the quality, environmental, security and occupational health management systems have a close relationship with the EFQM excellence model. If the management systems are already implemented, the requirements for the EFQM model can be satisfied in a much simpler way.

We also showed that the guidelines related to social responsibility presented in the Colombian norm GTC 180:2008 may be integrated to these systems, enabling organizations to have a an internal socially responsible approach. Complying with these guidelines would make it easier for organizations to abide by the principles presented in the international norm ISO 26000:2010, related to social responsibility.

With these relationships we demonstrated that COMPREHENSIVE SUSTAINABLE MANAGEMENT is directed towards a definite group of stakeholders, such as shareholders and investors, customers, suppliers, employees, the 
Table 1. Principles underlying the SGA_ISO $14001: 2004$ and the EFQM Excellence Model 2010.

\begin{tabular}{|c|c|}
\hline Principles of ISO 14001:2004 & Fundamentals EFQM: 2010 Excellece Model \\
\hline $\begin{array}{l}\text { Secure a demonstrable commitment to environmental } \\
\text { management. }\end{array}$ & - Adding value for customers \\
\hline - Promote continuous environmental improvement & - Leading with vision, inspiration and integrity. \\
\hline $\begin{array}{l}\text { To promote a wide interest within the public and the standard } \\
\text { users. }\end{array}$ & - Achieving succeeding through people. \\
\hline - Must be Practices that are useful and usable. & - Managing by Processes. \\
\hline - To Reduce environmental incidents that Lead to legal liability. & - Building partnerships. \\
\hline - Identify significant Environmental aspects of the Organization. & - Nurturing creativity and Innovation. \\
\hline Give importance to the evaluation of the Legal Fulfillment. & - Taking Responsibility for a Sustainable Future. \\
\hline & - Achieving balanced results. \\
\hline
\end{tabular}

Table 2. Criteria and sub-criteria of the EFQM model

1a. Leaders develop the mission, vision, values and ethics and act as role models.

1b. Leaders define, monitor, review and drive the improvement of the organisation's management system and performance.

1. Leadership

2. Strategy

3. People. 1c. Leaders engage with external stakeholders.

1d. Leaders reinforce a culture of excellence with the organisation's people.

1e. Leaders ensure that the organisation is flexible and manages change effectively.

2a. Strategy is based on understanding the needs and expectations of both stakeholders and the external environment.

2b. Strategy is based on understanding internal performance and capabilities.

2c. Strategy and supporting policies are developed, reviewed and updated to ensure economic, societal and ecological sustainability.

2d. Strategy and supporting policies are communicated and deployed through plans, processes and objectives.

3a. People plans support the organisation's strategy.

3b. People's knowledge and capabilities are developed.

3c. People are aligned, involved and empowered.

3d. People communicate effectively throughout the organisation.

3e. People are rewarded, recognised and cared for. 
Table 3. Relationship between criteria of ISO 14001:2004 and the EFQM Excellence Model 2010

\begin{tabular}{|c|c|c|c|c|c|c|c|c|c|c|c|c|c|c|}
\hline \multirow[b]{3}{*}{ ISO 14001:2004 } & \multicolumn{14}{|c|}{ EFQM CRITERIA } \\
\hline & \multicolumn{5}{|c|}{ Leadership } & \multicolumn{4}{|c|}{ Strategy } & \multicolumn{5}{|c|}{ People } \\
\hline & $a$ & $b$ & $c$ & $d$ & $e$ & $a$ & $b$ & $c$ & $d$ & $a$ & $b$ & $c$ & $d$ & $e$ \\
\hline 4. Requiriments Environmental Management System & & $\bullet$ & & & - & & & & & & & & & \\
\hline 4.1. Systemic requirements & & $\bullet$ & & & & & & & & & & & & \\
\hline 4.2. Policy requirements & $\bullet$ & • & & • & & & & . & • & & & & • & \\
\hline \multicolumn{15}{|l|}{ 4.3. Planning requirements } \\
\hline 4.3.1. Identify your environmental aspects. & & & $\bullet$ & & & • & & & & & & & & \\
\hline 4.3.2. Clarify legal and other requirements. & & & $\bullet$ & & & $\bullet$ & & & & & & & & \\
\hline 4.3.3. Establish objectives and programs. & & & & & & & & & • & & & & & \\
\hline \multicolumn{15}{|l|}{ 4.4. Operational requirements } \\
\hline 4.4.1. Provide resources and establish jobs. & $\bullet$ & • & & • & & & & & & & & & - & \\
\hline 4.4.2. Deliver training and awareness programs. & & & & & & & & & & & - & • & & \\
\hline 4.4.3. Establish communication procedures. & & • & & & & & & & & & & & & \\
\hline \multicolumn{15}{|l|}{ 4.4.4. Document your environmental management system. } \\
\hline \multicolumn{15}{|l|}{ 4.4.5. Control environmental management documents. } \\
\hline 4.4.6. Control environmentally significant operations. & & & $\bullet$ & & & & & & & & & & & \\
\hline \multicolumn{15}{|l|}{ 4.4.7. Establish an emergency management process } \\
\hline \multicolumn{15}{|l|}{ 4.5. Checking requirements } \\
\hline 4.5.1. Establish monitoring and measurement capabilities & & & & & & & $\bullet$ & & & & & & & \\
\hline \multicolumn{15}{|l|}{ 4.5.2. Evaluate legal and other compliance. } \\
\hline \multicolumn{15}{|l|}{ 4.5.3. Deal with your nonconformities. } \\
\hline \multicolumn{15}{|l|}{ 4.5.4. Control your environmental records. } \\
\hline \multicolumn{15}{|l|}{ 4.5.5. Perform internal environmental management audits } \\
\hline 4.6. Review requirements & & $\bullet$ & $\bullet$ & & & - & $\bullet$ & & & & & & & \\
\hline
\end{tabular}

community, and even the government when it relates to legal requirements. Also, more management systems could be added to this model if the organization so requires it.

\subsection{Methodological approach of the research project}

We designed the methodology of this research project as a process based on management systems under the ISO 9001:2008 norm (for quality management systems), the ISO 14001:2004 norm (for environmental management systems), the OHSAS 18001:2007 norm (for occupational health and safety systems), the model of excellence EFQM 2010 and the parameters of CSR.

Considering the described method, Figure 1 presents the methodology proposed to fulfill the objectives of the research project. The general methodological approach presents the relationships that should provide a good integration, therefore guiding an organization towards excellence.

In this manner we find the relationships between the management systems and the parameters of the CSR, in such a way that we can determine if an organization is socially responsible based on the correct implementation, execution and integration of its management systems.

This proposal includes a theory section, founded in a comprehensive literature search conducted on the subjects related to the project. Our approach also proposes fieldwork that we undertook as a case study (Yin, 1989; Bonache, 1999; Vásquez \& Angulo, 2003; Martínez, 2006). 

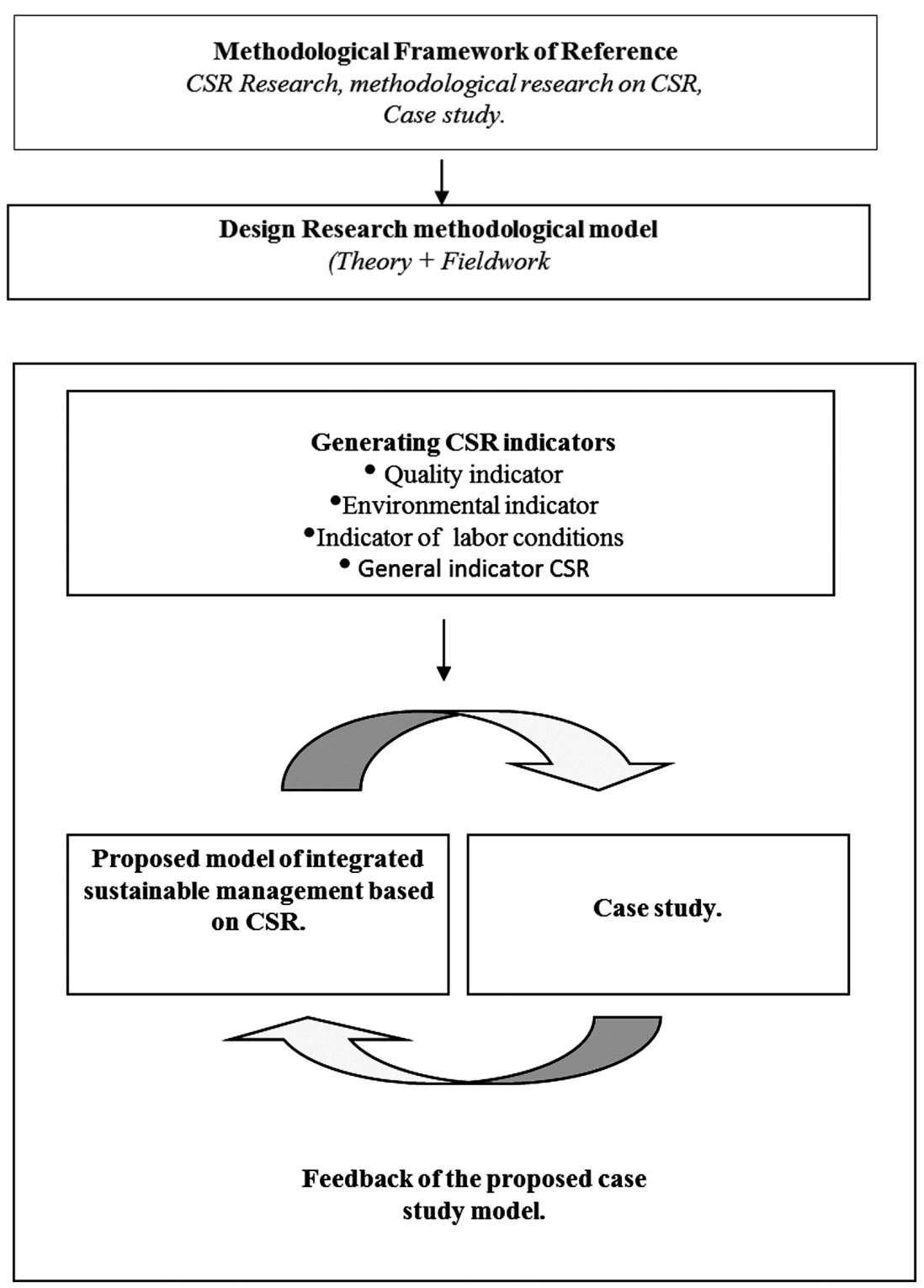

Figure 1. Methodological model proposed of the research project.

We found that some of the main works for the fundamental theoretical basis were ATEHORTÚA (2008), CCE (2001), FORO DE EXPERTOS (2005), GRI - G4 (2013), ISO 9000:2005, MELLADO (2006), RUSSEL (2000), OIT (2003), RODRÍGUEZ and RICART (2004), and UNGLOBAL COMPACT (2001).

We organized the theoretical proposal in two phases. The first phase included the integration of the models for quality, environmental, occupational health and safety management and their relationship to the model of excellence EFQM (Russel, 2000; Quintero, 2012). After this, we reviewed the parameters of CSR and their relationship with the Comprehensive Management System and the model of excellence EFQM, as presented in Figure 2.

We proposed these integrations considering the shared and non-shared characteristics of these management systems and their relationship with the parameters of CSR. 


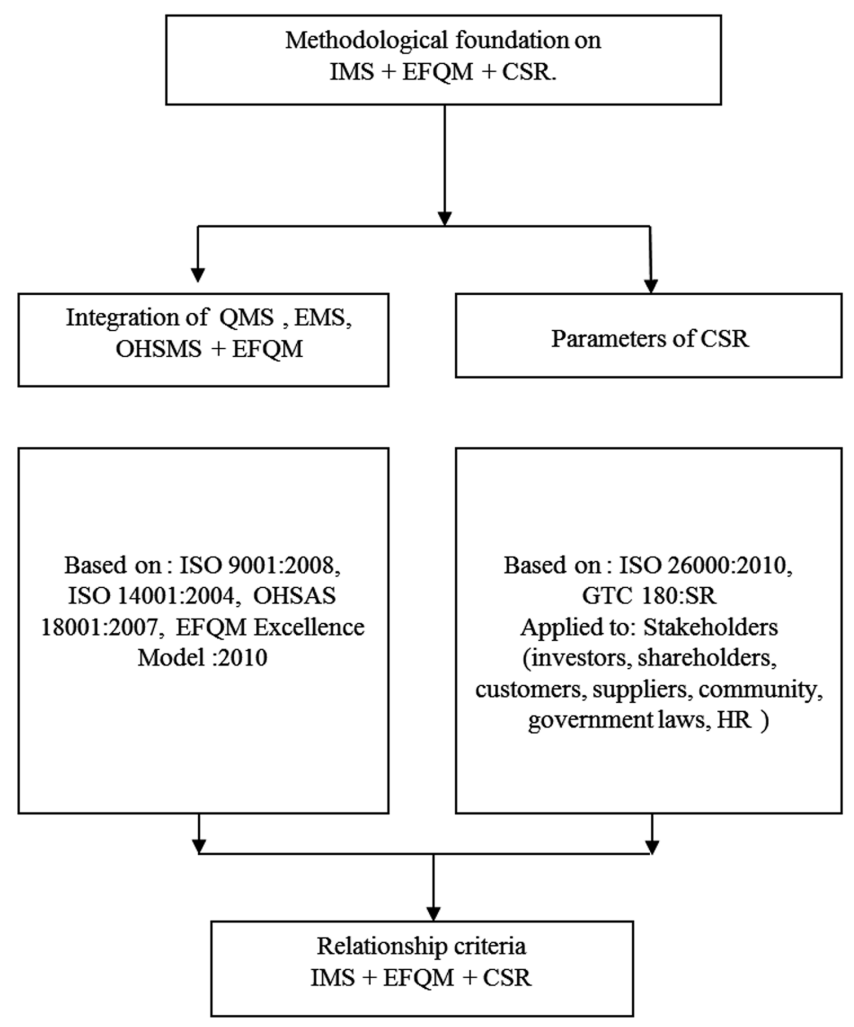

Figure 2. Methodological foundation of the proposed system of integrated sustainable management

Then, we applied what we proposed in the theoretical section through a case study, with the intent of verifying or refuting if these organizations are socially responsible, given that they have implemented the aforementioned management systems. To that end, we worked with two organizations in our region. One of them had certifications for the management systems of interest; the other one had implemented these management systems, but did not have certifications for them yet. It is worth noting that in this project we worked with two organizations, but the procedure could be applied to any organization.

\subsection{Case study}

For the case study and to check the theoretical approach used, two local organizations participated in this study. Fist, a survey was designed and applied to obtain the necessary information that showed the level of maturity (comprehension) that employees had about the management system in all levels. Then, a sample of the total number of workers was drawn from the process map of the organization and taking into account the number of workers involved in each process. It was a simple probabilistic draw with a proportional distribution, considering the weight of each process in the participating organizations. Table 4 presents an example of the procedure to obtain the sample in one of the organizations. We defined a measurement scale based on criteria from the experts in the organization and the researchers to analyze the results.

\section{Results and discussion}

\subsection{Structure of the generated model}

The methodological structure that is presented as the result of this research, demonstrated, how, using the integration and implementation of management systems, the EFQM excellence model and the principles of CSR, an organization could demonstrate that it is indeed a Socially 
Table 4. Calculation of sample size research $X X X X$

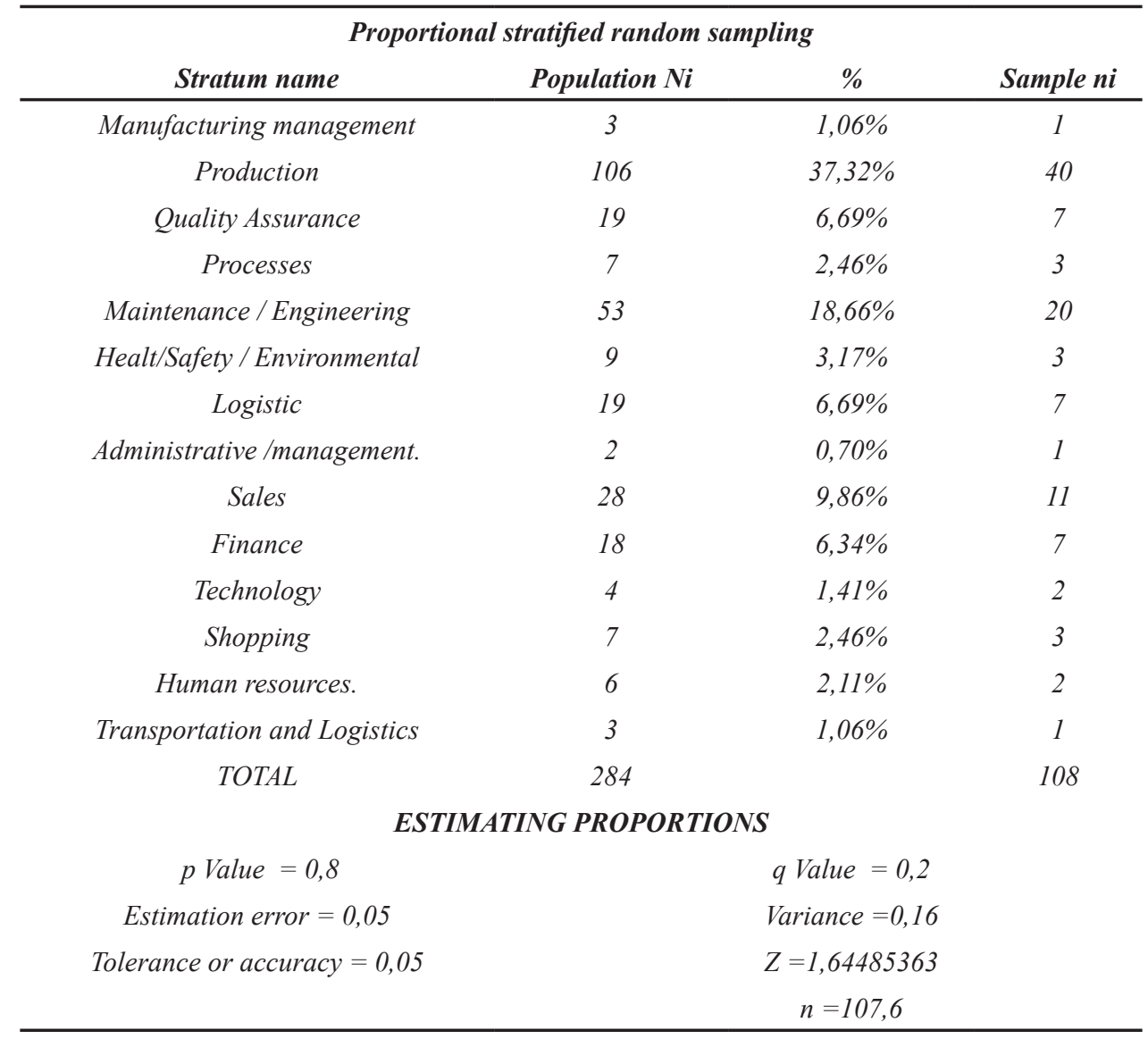

Responsible Organization (Quintero, 2012). In Figure 3 the steps used to generate the Model of Comprehensive Sustainable Management are shown. In the conceptual Model of Figure 4 the systemic vision of the different levels of relationships and integration between the different management systems can be seen; also it shows how the principles of Corporate Responsibility can constitute a framework where all of them support the Comprehensive Sustainable Management. CSR is the action framework for the EFQM excellence model, which in turn is the action framework for the quality managements systems (QMS), the environmental management system (EMS), the occupational health management system and the Corporate Responsibility management system.

The model presents a modular structure (see Table 5), where the variables or characteristics that were determined as common to justify the integration between each system considered, are shown. Also, the principles of Corporate Responsibility common to all the management systems are included.

Table 6 presents the Comprehensive Sustainable Management Model, which has incorporated the principles of the comprehensive management system such as: 1- Compromise and integrated policy, 2-Planning and assignment of responsibilities, 3- Process management, 4Legal and other requirements, 5- Continuous Improvement, 6- Staff, training and communication, 7-Documentation and control, 8- Measurements, evaluation and audits, where different relationships are evaluated according to the strong, weak or marginal presence.

Also, the model has a structure according to the phase of the PDCA management cycle with a socially responsible focus. 


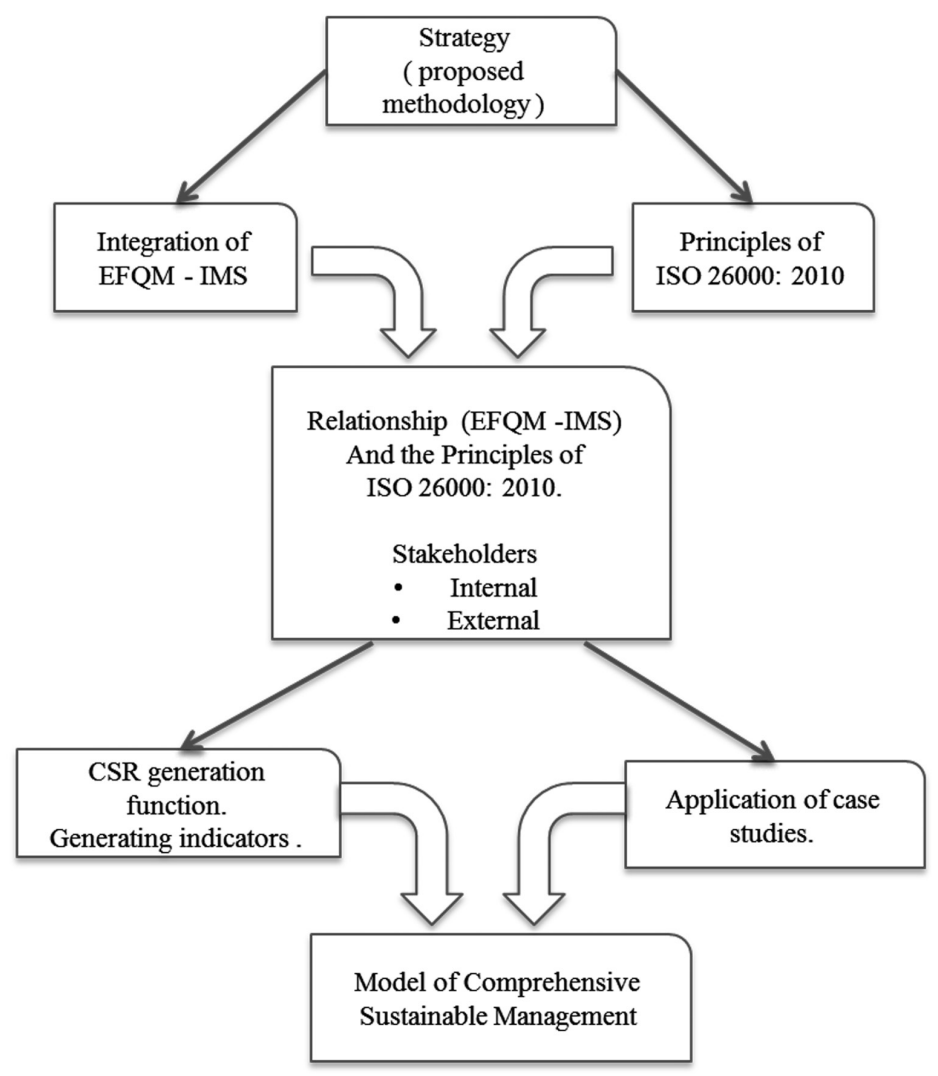

Figure 3. The proposed model generation

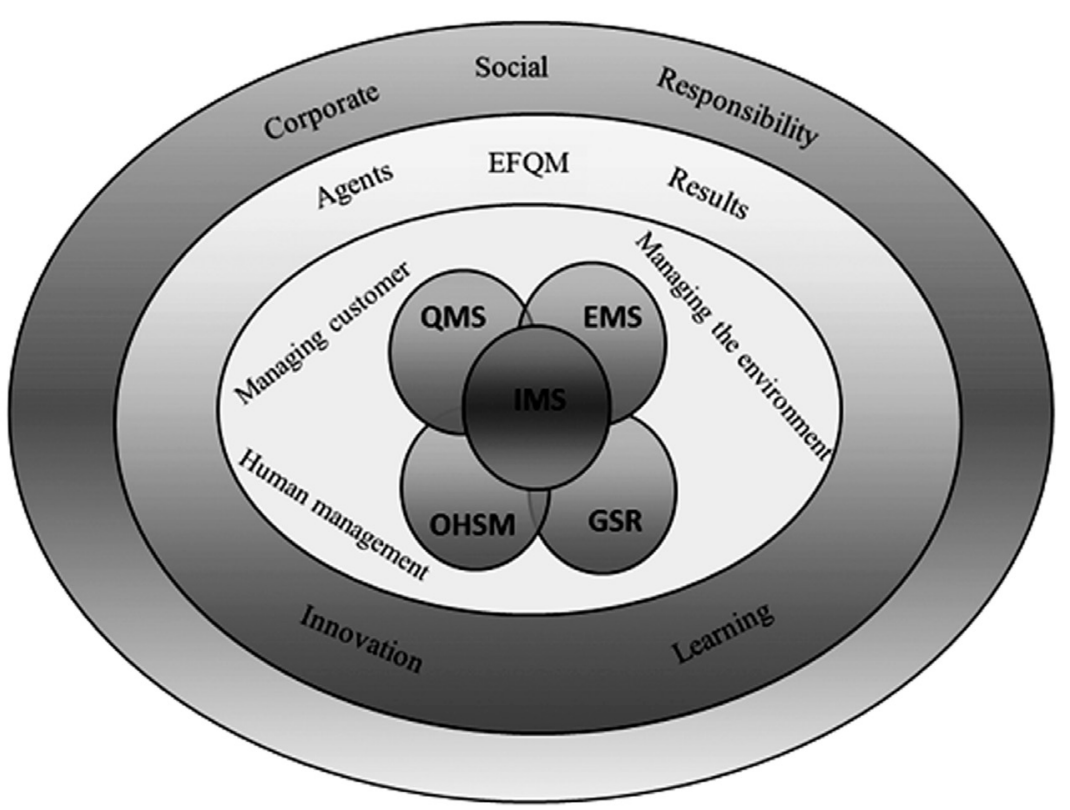

Figure 4. QMS: Quality Management System, EMS: Environmental Management System, OHMS: Occupational Health Management System, IMS: Integrated Management System, GSR :Guidance on Social Responsibility 
Table 5. Modular structure. Model of integrated sustainable management. $X=$ strong presence; $\quad 0=$ weak presence; $\quad \mathbf{\Delta}=$ marginal presence

\begin{tabular}{|c|c|c|c|c|c|}
\hline \multirow[t]{2}{*}{ INTEGRATED MODEL } & \multicolumn{5}{|c|}{$\begin{array}{c}\text { PRINCIPLES OF SOCIAL RESPONSIBILITY. Transparency. Respect. Ethical } \\
\text { behavior. Respect for human rights. Respect for the law. Respect international } \\
\text { norms of behavior. }\end{array}$} \\
\hline & $\begin{array}{c}\text { GTC } \\
\text { 180: } R S\end{array}$ & EFQM:2010 & $\begin{array}{c}I S O \\
9001: 2008\end{array}$ & $\begin{array}{c}\text { ISO } \\
14001: 2004\end{array}$ & $\begin{array}{c}\text { OHSAS } \\
18001: 2007\end{array}$ \\
\hline \multicolumn{6}{|l|}{$\begin{array}{l}\text { BLOCK 1. Integrated Management } \\
\text { Systems. }\end{array}$} \\
\hline PDCA Cycle & $X$ & 0 & $X$ & $X$ & $X$ \\
\hline Prevention principles & $X$ & 0 & $X$ & $X$ & $X$ \\
\hline Process Management & $X$ & $X$ & $X$ & $X$ & $X$ \\
\hline Similiar evidence base & $X$ & 0 & $X$ & $X$ & $X$ \\
\hline \multicolumn{6}{|l|}{$\begin{array}{l}\text { BLOCK 2. Relationship } \\
\text { INTEGRATED MANAGEMENT } \\
\text { SYSTEM WITH EFQM MODEL }\end{array}$} \\
\hline $\begin{array}{c}\text { Commitment and comprehensive } \\
\text { policy. }\end{array}$ & $X$ & $X$ & $X$ & $X$ & $X$ \\
\hline $\begin{array}{c}\text { Planning and assignment of } \\
\text { responsibilities. }\end{array}$ & $X$ & $X$ & $X$ & $X$ & $X$ \\
\hline Managing by Processes. & $X$ & $X$ & $X$ & $X$ & $X$ \\
\hline Legal and other requirements. & $X$ & $X$ & $X$ & $X$ & $X$ \\
\hline Staff training and communication. & $X$ & $X$ & $X$ & $X$ & $X$ \\
\hline Documentation and control. & $X$ & $X$ & $X$ & $X$ & $X$ \\
\hline Continuous improvement. & $X$ & $X$ & $X$ & $X$ & $X$ \\
\hline $\begin{array}{c}\text { Measurement, evaluation and } \\
\text { auditing. }\end{array}$ & $X$ & $X$ & $X$ & $X$ & $X$ \\
\hline \multicolumn{6}{|l|}{$\begin{array}{l}\text { BLOCK 3. Relationship of } \\
\text { integrated management systems } \\
\text { and EFQM model with CSR (Focus } \\
\text { from Stakeholders). }\end{array}$} \\
\hline $\begin{array}{l}\text { Relationship Market Value - } \\
\text { Quality. Shareholders / investors. } \\
\text { Customers / suppliers. }\end{array}$ & $X$ & $X$ & $X$ & $X$ & $X$ \\
\hline $\begin{array}{l}\text { Relationship occupational health } \\
\text { with Human Resource. }\end{array}$ & $X$ & $X$ & $X$ & $X$ & $X$ \\
\hline $\begin{array}{c}\text { Relationship IMS - Community - } \\
\text { society. }\end{array}$ & $X$ & $X$ & $X$ & $X$ & $X$ \\
\hline $\begin{array}{c}\text { Relationship IMS - Government - } \\
\text { legal requirements. }\end{array}$ & $X$ & $X$ & $X$ & $X$ & $X$ \\
\hline
\end{tabular}




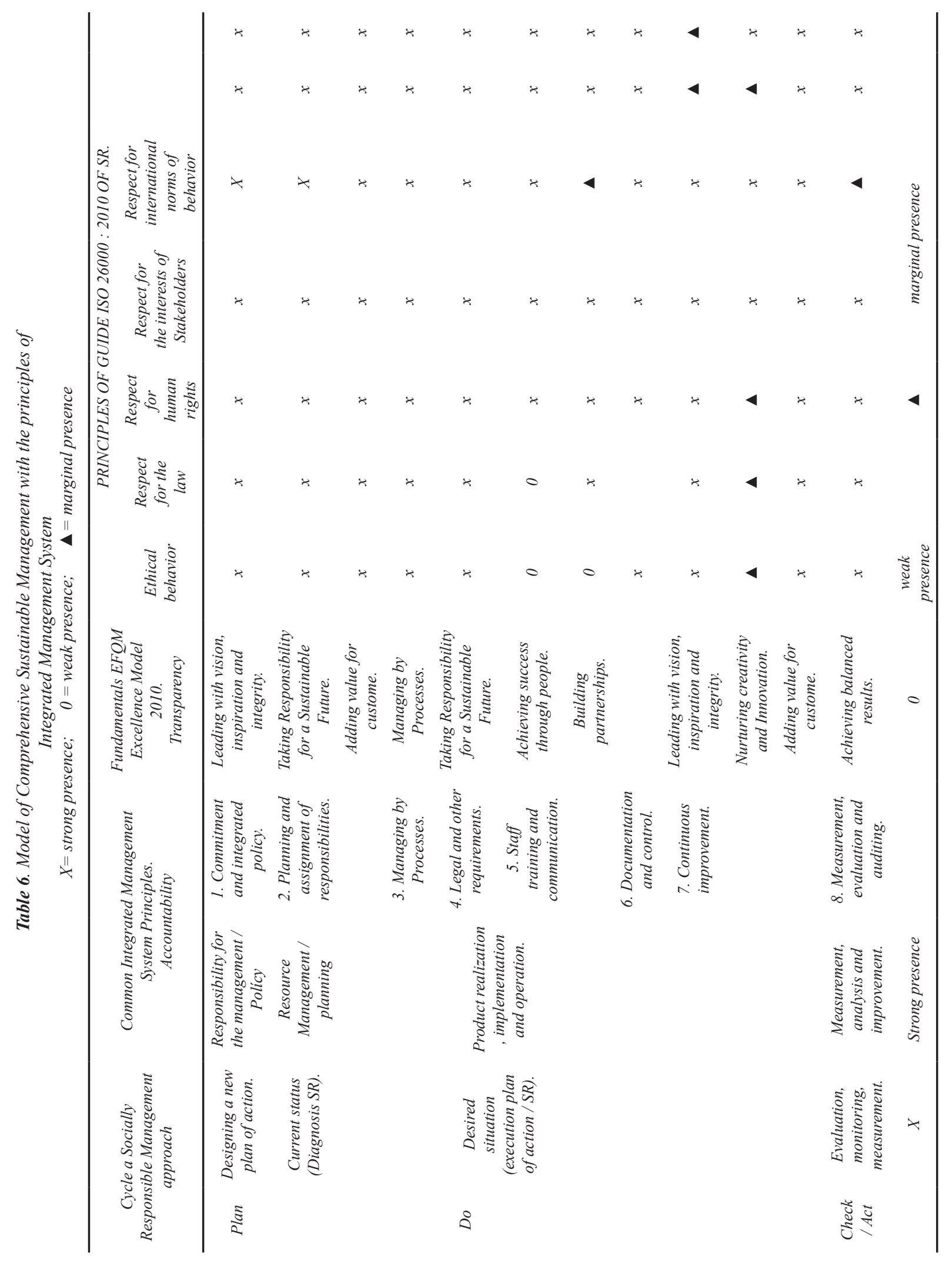




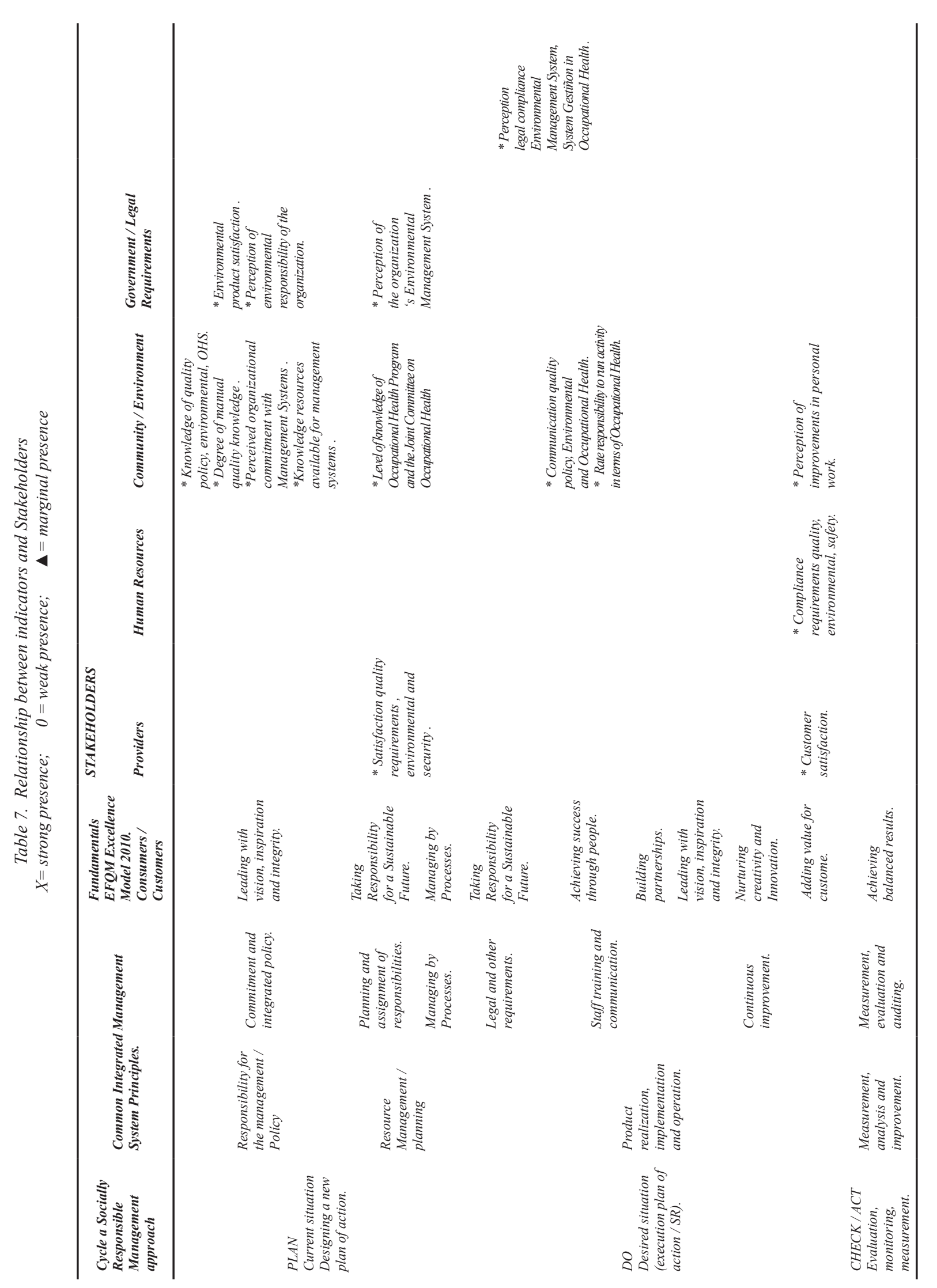


The case studies were developed with two organizations that represent local and national industry in Colombia, and they willingly participated in this step of this research project.

As a part of the practical application y according to the proposed methodology, a survey was done, so the answers gave the information input needed to finish our work.

\subsection{CSR indicators}

As a complement to the Comprehensive Sustainable management model, we present the suggested indicators, previouslydeterminedandjustified, based on the Guide for the elaboration of Sustainability Memoirs - GRI (GRI, 2002;GRI-G4, 2013; Quintero, 2012).

The indicators were generated taking into account the stakeholders affected according to the requirements of each management system and the guidelines presented in SR ISO 26000.2010 and the GTC 180. Table 7 shows these indicators for each stakeholder.

\section{Conclusions}

The current context of high competitiveness, due to the presence of open markets and globalization, enhances the importance that quality, environmental and occupational health management systems have acquired at a global level.

The aforementioned systems do have a close relationship with the EFQM excellence model, as it was proven. Thus, if the systems are implemented, los requirements of the EFQM model can be fulfilled in a much simpler way.

The synergy between the different management systems and the guiding principles and foundations of corporate responsibility, based on the ISO 26000:2010 international guidelines and the Colombian norm GTC 180 on Corporate Responsibility was proven. An important issue that has to be mentioned is the decision to include the PCDA cycle with a socially responsible approach, after reviewing what was said in the
GTC 180 about Social Responsibility.

A management cycle with this approach is applicable to systems that can integrate a single management system, using common elements of every part of the cycle, involving the principles of corporate responsibility, for eachaction, that is what constitutes COMPREHENSIVE SUSTAINABLE MANAGEMENT.

Thus, the principles of social responsibility come into the spotlight; the ethical alignment is a focal point for the execution of the continuous improvement cycle and the social responsibility principles mentioned in the international norm ISO 26000:2010 have to be taken into consideration.

The proposed model can be a interesting contribution for any improvement or implementation initiative of a Corporate Social Responsibility program. However, the model presents general guidelines that have to be adjusted to each particular case.

It is important to remark that the results we obtained come from a novel research approach, and that we have not found similar values and indicators in the academic literature.

Another noteworthy aspect is that this is an individual measurement and that it comes from an organization-specific analysis. Thanks to the percent-based scale, which we used to measure the data we gathered, the values we obtain correspond to a specific degree of development of the variable we measured.

We can conclude, based on the results obtained in this research project, that an organization can use the percentage obtained in the degree of maturity of its management systems as a proxy for its performance in regards to the development of its CSR. This is due to the fact that the more the organization complies with the requirements of the management systems, the more it will be in compliance with the principles of the CSR, based on the relationships that were demonstrated in this research.

Therefore, we contend that we propose a novel model to determine the degree of development 
of Corporate Social Responsibility in an organization with an approach that comes from the quality, environment and occupational health management systems.

\section{References}

Atehortúa, H. (2008). Responsabilidad social empresarial: entre la ética discursiva y la Racionalidad técnica. Revista Escuela de Administración de Negocios, (62), 125-139.

Bonache, J. (1999). El estudio de casos como estrategia de construcción teórica: características, críticas y defensas. Cuadernos de Economía y Dirección de la Empresa, (3),123-140.

CCE (Comisión de las Comunidades Europeas) (2001). Libro Verde: Fomentar un marco europeo para la Responsabilidad Social de las empresas. Documento preparado para la Unión Europea. Brussels.

Cortina, A. (2003). Construir Confianza. Ética de la Empresa en la sociedad de la información y las comunicaciones. Madrid, Spain: Editorial Trotta S.A.

Cortina, A. (2005). Ética de la Empresa. Claves para una nueva cultura empresarial. Seventh Edition. Madrid, Spain: Editorial Trotta S.A.

EFQM. (2010). Introducing the EFQM Excellence Model 2010. Extracted in 2010 from: http:// www.efqm.org/en/PdfResources/EFQMModel Presentation.pdf

FORO DE EXPERTOS. Ministry of Work and Immigration (2005). I, II y III Sesión de trabajo de foro de expertos en RSE. Definición y Ámbito de la RSE. Spain. Extracted in 2008 from: http:// gencat.es/treball/doc/doc_56906710_1.pdf.

Galeano, M. (2004). Estudio cualitativo de caso: el interés por la singularidad. In: Estrategias de investigación social cualitativa. El giro de la mirada. Medellín, Colombia: La Carretera Editores, (Capítulo 2).

García-Marzá,D.(2006).Éticaempresarial:Unmarco para la definición y gestión de la Responsabilidad
Social Corporativa. In: Mitos y Realidades de la Responsabilidad Social Corporativa en España. Un enfoque multidisciplinar. Navarra, Spain: Editorial Aranzadi S.A., (Capítulo 3).

GRI - G4 (Global Reporting Initiative) (2013). SUSTAINABILITY REPORTING GUIDELINES. Extracted from: https://www.globalreporting.org/ reporting/g4/Pages/default.aspx

GRI (Global Reporting Initiative) (2002). Guía para la Elaboración de Memorias de Sostenibilidad sobre el desempeño económico, ambiental y social de la empresa. Extracted from: www.globalreporting.org

GTC 180. (2008). Guía Técnica Colombiana en responsabilidad social. Bogotá, D.C., Colombia: Edited by Instituto Colombiano de Normas Técnicas y Certificación (ICONTEC).

ISO. (2005). ISO 9000. Norma internacional. Certified Translation. Sistemas de gestión de la calidad - Fundamentos y vocabulario. Switzerland. ISO Copyright office.

ISO (2010). ISO 26000. Norma Internacional. Official Translation. Guía de responsabilidad social. Spanish versión. Switzerland. ISO Copyright office.

Martínez, P. (2006). El método de estudio de caso. Estrategia metodológica de la Investigación científica. Revista Pensamiento y Gestión. (20), 165-193.

Mellado, Ma. D. (2006) La gestión integrada de la calidad, el medio ambiente y la prevención de riesgos laborales en las organizaciones. Madrid: Editorial Universitaria Ramón Areces.

NTC-ISO 14001:2004 (2004). Norma Técnica Colombiana. Sistemas de gestión ambiental. Requisitos con orientación para su uso. Bogotá, D.C. Colombia: Edited by Instituto Colombiano de Normas Técnicas y Certificación (ICONTEC).

NTC-ISO 9001:2008 (2008). Norma Técnica Colombiana. Sistemas de gestión de la calidad requisitos. Bogotá, D.C., Colombia: Editada por el Instituto Colombiano de Normas Técnicas y Certificación (ICONTEC). 
NTC-OHSAS 18001:2007 (2007). Norma Técnica Colombiana. Sistemas de gestión en seguridad y salud ocupacional - requisitos. Bogotá, D.C., Colombia: Edited by Instituto Colombiano de Normas Técnicas y Certificación (ICONTEC).

OIT (2003). Nota Informativa sobre RSE y normas internacionales de trabajo. Extracted in 2008 from: http://www.ilo.org/public/spanish/ standards/relm/gb/docs/gb288/pdf/sdf3.pdf

Piñeros, E. R. (2007). Medición diagnostica de la Ética y de la Responsabilidad Social Empresarial como factores de perdurabilidad. Universidad Empresa 6 (12), 225-260.

Quintero, M. (2012). Gestión Sostenible Integral: La Responsabilidad Social Empresarial en la Integración de los Sistemas de Gestión. Doctoral Dissertation Universidad Politécnica de Valencia. Doctoral Program in Management. Valencia, Spain.

Rodríguez, M. \& Ricart, J. (2000). Coordinación de los sistemas de gestión de calidad, medio ambiente y salud laboral (Parte I). Harvard Deusto business review. (97), 54-60.

Russell, S. (2000). ISO 9000:2000 and the EFQM Excellence model: competition or co-operation? Total Quality Management. 11(4/5), 657- 665.
Schuschny, A., Soto, H. (2009). Guía metodológica. Diseño de indicadores compuestos de desarrollo sostenible. Naciones Unidas. Comisión Económica para AméricaLatinayelCaribe(CEPAL).Bundesministerium für Wirtschaftliche Zusammenarbeit und Entwicklung. Colección documentos de proyectos. United Nations Publication. May. Santiago de Chile, Chile.

Scribano, A.; Gandia, C. \& Magallanes, G. (2006). La enseñanza de la "metodología de la investigación" en ciencias sociales. Ciencias Sociales Online, 3(1), $91-102$.

Tamayo, M. (1999). La Investigación. Serie aprender a investigar. Módulo 2. Instituto colombiano para el fomento de la educación superior, ICFES. Bogota DC., Colombia.

UNGLOBAL COMPACT. (2001). El Pacto Mundial. Naciones Unidas. Extracted in 2008 from: http://www.unglobalcompact.org

Vásquez, R., Ángulo, F. (2003). Los estudios de caso en educación. Una aproximación teórica. Introducción a los estudios de casos. Los primeros contactos con la investigación etnográfica. Ediciones Aljibe, Málaga: Spain.

Yin, Robert K. (2003). Case study research. Design and methods. Applied social research methods series. California. Sage Publications, Inc.

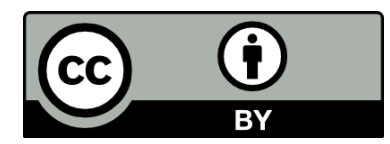

Revista Ingeniería y Competitividad por Universidad del Valle se encuentra bajo una licencia Creative Commons Reconocimiento - Debe reconocer adecuadamente la autoría, proporcionar un enlace a la licencia e indicar si se han realizado cambios. Puede hacerlo de cualquier manera razonable, pero no de una manera que sugiera que tiene el apoyo del licenciador o lo recibe por el uso que hace. 